\title{
HEAVY METALS AND MICRONUTRIENTS IN THE SOIL AND GRAPEVINE UNDER DIFFERENT IRRIGATION STRATEGIES
}

\author{
Vanessa de Souza Oliveira(1), Augusto Miguel Nascimento Lima(1)*, Alessandra Monteiro \\ Salviano(2), Luís Henrique Bassoi(2) and Giuliano Elias Pereira(3)
}

(1) Universidade Federal do Vale do São Francisco, Colegiado de Graduação em Engenharia Agronômica, Campus Ciências Agrárias, Petrolina, Pernambuco, Brasil.

(2) Empresa Brasileira de Pesquisa Agropecuária - Embrapa Semiárido, Petrolina, Pernambuco, Brasil.

(3) Empresa Brasileira de Pesquisa Agropecuária - Embrapa Uva e Vinho/Semiárido, Petrolina, Pernambuco, Brasil.

* Corresponding author.

E-mail: augusto.lima@univasf.edu.br

\begin{abstract}
Soils under natural conditions have heavy metals in variable concentrations and there may be an increase in these elements as a result of the agricultural practices adopted. Transport of heavy metals in soil mainly occurs in forms dissolved in the soil solution or associated with solid particles, water being their main means of transport. In this context, the aim of this study was to evaluate the heavy metal and micronutrient content in the soil and in the grapevine plant and fruit under different irrigation strategies. The experiment was carried out in Petrolina, PE, Brazil. The treatments consisted of three irrigation strategies: full irrigation (FI), regulated deficit irrigation (RDI), and deficit irrigation (DI). During the period of grape maturation, soil samples were collected at the depths of 0-10, 10-20, 20-40, 40-60, and 60-80 cm. In addition, leaves were collected at the time of ripening of the bunches, and berries were collected at harvest. Thus, the heavy metal and micronutrient contents were determined in the soil, leaves, and berries. The heavy metal and micronutrient contents in the soil showed a stochastic pattern in relation to the different irrigation strategies. The different irrigation strategies did not affect the heavy metal and micronutrient contents in the vine leaves, and they were below the contents considered toxic to the plant. In contrast, the greater availability of water in the FI treatment favored a greater $\mathrm{Cu}$ content in the grape, which may be a risk to vines, causing instability and turbidity. Thus, adoption of deficit irrigation is recommended so as to avoid compromising the stability of tropical wines of the Brazilian Northeast.
\end{abstract}

Keywords: water availability, nutrients, grape. 


\title{
RESUMO: METAIS PESADOS E MICRONUTRIENTES NO SOLO E NA VIDEIRA SOB DIFERENTES ESTRATÉGIAS DE IRRIGAÇÃO
}

\begin{abstract}
Os solos naturalmente possuem metais pesados em teores variáveis, podendo ocorrer incremento desses elementos em razão de práticas agrícolas adotadas. Otransporte de metais pesados no solo ocorre, principalmente, nas formas dissolvidas na solução desse ou associado às partículas sólidas, sendo a água sua principal via de transporte. Nesse contexto, este trabalho teve por objetivo avaliar o teor de metais pesados e micronutrientes no solo, na planta e nos frutos de videira, submetida a diferentes estratégias de irrigação. Oexperimento foi instalado em Petrolina, PE. Os tratamentos foram constituídos de três estratégias de irrigação: IP (irrigação plena); IDC (irrigação com déficit controlado); e ID (irrigação com déficit). Durante o período de maturação da uva, foram coletadas amostras de solo nas profundidades de 0-10; 10-20; 20-40; 40-60; e 60-80 cm. Também foram coletadas folhas, no momento da maturação dos cachos, e bagas, no instante da colheita. Determinaram-se no solo, na folha e baga os teores de metais pesados e micronutrientes. Os teores de metais pesados e micronutrientes no solo apresentaram padrão estocástico em relação às diversas estratégias de irrigação. As diferentes estratégias de irrigação não influenciaram os teores de metais pesados e micronutrientes na folha de videira, estando esses abaixo dos teores considerados tóxicos para a planta. Entretanto, a maior disponibilidade de água no tratamento com IP favoreceu maior teor de Cu na uva, podendo ser um risco para os vinhos, causando instabilidade e turbidez. Dessa forma, recomenda-se adotar irrigação com déficit, evitando-se assim comprometer a estabilidade de vinhos tropicais da região Nordeste do Brasil.
\end{abstract}

Palavras-chave: disponibilidade de água, nutrientes, uva.

\section{INTRODUCTION}

Chemical elements with a density greater than $6 \mathrm{~kg} \mathrm{dm}^{-3}$ are considered to be heavy metals (Hooda, 2010). Of these, more than 20, called micronutrients, are essential to the life cycle of plants, animals, and human beings. Among these are $\mathrm{Cu}, \mathrm{Fe}, \mathrm{Mn}, \mathrm{Ni}$, and $\mathrm{Zn}$ (Kabata-Pendias, 2011). Depending on the contents and the environmental physicochemical conditions, such elements may pass from the condition of micronutrients to that of toxic elements, acting as contaminating agents of the soil, water, and air (Larcher, 2004). However, some heavy metals, like $\mathrm{Pb}, \mathrm{Hg}$, $\mathrm{As}$, and $\mathrm{Cd}$, do not have any biological activity and, even at low concentrations, may have a harmful effect on plants (Lasat, 2002).

Soils in their natural state have heavy metals at varied concentrations, depending on the material of origin and the processes involved in their formation (Fadigas et al., 2006). There may also be deposition in the soil through industry or use of agricultural inputs such as fertilizers and pesticides (Xue et al., 2003), or diffuse contamination through deposit of aerosols on the soil surface.

The frequency and intensity of rains, temperature, and evaporation, as well as edaphic conditions, are among the factors that most affect the dynamic of heavy metals in the environment and their consequent solubility, mobility, and uptake by plants (Kabata-Pendias, 2011). The process of plant uptake of these elements will occur through their contact with plant roots, and this process is dependent on the mechanisms of mass flow transport and diffusion. For this transport to occur, the elements must be in a soluble form or associated with mobile ligands in the soil (Cunha et al., 1996).

Soils under irrigated cropping normally undergo changes of a chemical, physical, and biological order in a relatively short time and at an intensity that varies in accordance with the quality and quantity of the water applied, management practices, use of fertilizers, and the chemical and physical characteristics of the soils (Silva and Araújo, 2005). The region of the Vale do Submédio São Francisco (Lower-Middle São Francisco River Valley) is characterized by climatic conditions that make the use of irrigation indispensable for satisfactory plant development. Excess water, in addition to decreasing oxygen concentration (Pires et al., 2002), contributes to nutrient loss through leaching, especially in sandy soils. In contrast, lack of water significantly reduces plant nutrient uptake by compromising the diffusion and flux of nutrient mass in the soil (Novais and Smyth, 1999).

The mineral element composition of grape is varied. These elements are taken up through the grapevine root system, and enrichment is observed during berry formation and maturation, affecting the final composition of the wine. Enrichment with some metals may lead to detrimental effects on quality, such as turbidity, precipitation, and oxidations (Catarino et al., 2008). In addition, according to the same researchers, depending on the concentration of the element present, problems of a toxicological and legal order may arise.

One of the main problems in vineyards irrigated for the purpose of obtaining quality grapes and 
wines is the increase in vegetative vigor, causing an imbalance between leaf area and fruit production (Keller et al., 2008). The high vigor of shoots due to excessive irrigation increases competition for photoassimilates between fruits and shoots, changes the microclimate in the vicinity of the bunches (compromising synthesis of phenolic compounds), reduces the fertility of the buds, and creates difficulties in plant health treatments (Jackson and Lombard, 1993). Irrigation management has been one of the main resources for controlling vegetative vigor of the plant in recent years since composition of the grape berry is strongly affected by the moisture conditions of the grapevine (Dry and Loveys, 1998). Based on this principle, deficit irrigation strategies have been presented, seeking to establish balance between vegetative development and grape yield, without harming the qualitative aspects of the grapes (McCarthy, 1997). In addition, appropriate irrigation management constitutes an excellent opportunity for rational use of water resources.

In this context, the aim of this study was to evaluate the heavy metal and micronutrient contents in the soil, in the plant, and in the fruits of grapevines under different irrigation strategies in the region of the Vale do Submédio São Francisco, Brazil.

\section{MATERIAL AND METHODS}

The experiment was carried out in the Bebedouro Experimental Field, belonging to Embrapa Semiárido in Petrolina, PE, Brazil, at latitude $9^{\circ} 08^{\prime} 08.9^{\prime \prime} \mathrm{S}$, longitude $40^{\circ} 18^{\prime} 33.6^{\prime \prime} \mathrm{W}$, and altitude of $373 \mathrm{~m}$. According to the Geoviticulture Multicriteria Climatic Classification System, the region has a climate classification of $\mathrm{IS}_{1} \mathrm{IH}_{6} \mathrm{IF}_{1}$, with moderate dryness and very hot climate, and hot nights (Tonietto, 1999). Mean annual values of the climate variables are: air temperature: $26.5^{\circ} \mathrm{C}$, rainfall: $541.1 \mathrm{~mm}$, relative air humidity: $65.9 \%$, class "A" evaporation pan: $2,500 \mathrm{~mm} \mathrm{yr}^{-1}$, and wind speed: $2.3 \mathrm{~m} \mathrm{~s}^{-1}$. Rainfall is irregularly distributed in space and time, concentrated in December to April; annual solar radiation is greater than 3,000 h (Azevedo et al., 2003). Soil in the area was classified as an Ultisol (Silva, 2005), originating from alteration of the cobble covering schists from the Pre-Cambrian Eon (mica schists).

The Syrah grape cultivar (Vitis vinifera L.) on the 'Paulsen 1103' rootstock (Vitis berlandieri $\mathrm{x}$ Vitis ruprestis) was chosen. The grapevines were planted on April 30, 2009 at a spacing of $3.0 \times 1.0(3.0 \mathrm{~m}$ between rows and $1.0 \mathrm{~m}$ between plants). At planting, fertilization for establishment of the vineyard was carried out with application of limestone (200 g per linear meter), goat manure (40 $\left.\mathrm{m}^{3} \mathrm{ha}^{-1}\right)$, and granulated single superphosphate $\left(18 \% \mathrm{P}_{2} \mathrm{O}_{5}\right)(50 \mathrm{~g} / \mathrm{plant})$. In production fertilization, only goat manure was applied, at the rate of $0.02 \mathrm{~m}^{3} / \mathrm{plant}$. The vineyard is trained in vertical shoot positioning and the pruning system is a bilateral spur pruned cordon de Royat.

The period of trellised vine formation (vegetative growth) was up to April 13, 2010, at which time the vines were pruned to begin the first production cycle. This study was carried out in the third production cycle, from May 10, 2011 to September 8,2011 . Drip irrigation was used at a flow rate of $2.5 \mathrm{~L} \mathrm{~h}^{-1}$, with nozzles spaced at $0.5 \mathrm{~m}$ in the plant row and service pressure of $100 \mathrm{kPa}$, calibrated in a field flow test. Calculation of irrigation was made using reference evapotranspiration (ETo) estimated by the Penman-Monteith FAO method through parameters measured by the automatic meteorological station set up approximately $60 \mathrm{~m}$ from the area of the experiment. In determination of the crop evapotranspiration values (ETc), the Kc values recommended by Bassoi et al. (2007) were used. The agricultural chemicals used in pest and disease control in the area during the experiment were Equation ${ }^{\circledR}$ (misture of ciymoxanil and famoxadone) and Forum ${ }^{\circledR}$ (dimethomorph) in control of mildew, at the rate of $1,000 \mathrm{mg} \mathrm{L}^{-1}$ (two applications); and Rumo ${ }^{\circledR}$ (indoxacarb) in control of citrus stem borer, at the rate of $80 \mathrm{mg} \mathrm{L}^{-1}$ (one application). For control of rust, Rubigam ${ }^{\circledR}$ (fenarimol) was applied at the rate of $350 \mathrm{mg} \mathrm{L}^{-1}$ (one application); and for powdery mildew, Amistar ${ }^{\circledR}$ (misture of azoxystrobin and difenoconazole) and Cabrio top ${ }^{\circledR}$ (pyraclostrobin) were applied at the rate of $600 \mathrm{mg} \mathrm{L}^{-1}$ (one application).

The experimental area was composed of 24 rows with 24 plants per row, for a total of 576 plants, and, of these, only the 12 central plants of each row were evaluated, for a total of 288 useful plants. The treatments consisted of three irrigation strategies: full irrigation (FI), where irrigation was carried out to restore the water depth corresponding to the quantity of water evapotranspired, without water restriction to the grapevines throughout the entire production cycle; regulated deficit irrigation (RDI), where water application was interrupted as of the bunch closure phenological phase (45 dapp - days after production pruning), but carried out at 70,71 , 87, 90, and 111 dapp, for the purpose of increasing soil moisture $\left(\theta, \mathrm{m}^{3} \mathrm{~m}^{-3}\right)$ at the effective depth of the grapevine root system $(0.6 \mathrm{~cm})$, taking the soil moisture conditions into consideration, monitored weekly by the neutron moderation technique at $15,30,45,60,75,90,105$, and $120 \mathrm{~cm}$ of depth; and deficit irrigation (DI), where water application was interrupted as of 45 dapp, bunch closure phenological phase, up to harvest at 115 dapp. The treatments were arranged in a randomized block design with four replications. 
During the grape maturation period, soil samples were collected in the 0-10, 10-20, 20-40, 40-60, and 60-80 $\mathrm{cm}$ depth layers, removing six simple samples from each depth to obtain one combined sample per plot. The soil samples were air-dried, broken up, homogenized, and passed through a sieve with a $2.0 \mathrm{~mm}$ mesh to obtain air-dried soil samples. The physical soil analyses of bulk density, particle density, and texture were determined, according to the methods described by Claessen (1997). In chemical characterization, $\mathrm{pH}\left(\mathrm{H}_{2} \mathrm{O}\right)$, electrical conductivity in the saturated paste extract $\left(\mathrm{EC}_{\mathrm{se}}\right)$, potential acidity $(\mathrm{H}+\mathrm{Al})$, soil organic matter content, and CEC and base saturation (V) were determined (Table 1), according to the methods proposed by Silva (2009). In addition, contents of $\mathrm{Fe}, \mathrm{Mn}, \mathrm{Cu}, \mathrm{Zn}, \mathrm{Cr}, \mathrm{Ni}$, $\mathrm{Cd}$, and $\mathrm{Pb}$ were determined, after extraction with Mehlich-1 (0.05 mol L-1 $\left.\mathrm{HCl}+0.0125 \mathrm{~mol} \mathrm{~L}^{-1} \mathrm{H}_{2} \mathrm{SO}_{4}\right)$ at the ratio of $1: 5$ (soil:solution), with reading made by atomic absorption spectrophotometry (AAS) according to the methods proposed by Claessen (1997).

At the beginning of grape maturation (which occurred on August 3, 2011, at 85 dapp), samples of plant tissue were collected from whole leaves opposite the bunch, two leaves per plant (Albuquerque et al., 2009). Only leaves without damage and without any type of contamination were collected. For the grape samples (berries), collections were made at the time of harvest, taking three bunches per block for each treatment (randomly) as samples, collecting whole and healthy bunches. The plant material (leaves and berries) were dried in an air circulation laboratory oven at $70^{\circ} \mathrm{C}$ for $72 \mathrm{~h}$, weighed, and passed through a Willey mill. The plant material (leaves and berries) was then mineralized by a nitric-perchloric acid mixture (3:1) for chemical analysis. Determination of micronutrients (Fe, Mn, $\mathrm{Cu}$, and $\mathrm{Zn}$ ) and heavy metals $(\mathrm{Ni}, \mathrm{Cd}, \mathrm{Cr}$, and $\mathrm{Pb}$ ) present in the extracts of leaves and berries was carried out by atomic absorption spectrophotometry (AAS), according to the methods proposed by Miyazawa et al. (2009). Crop yield (kg ha-1) in all the treatments was estimated from the data obtained from fruit production per plot ( $\mathrm{kg} \mathrm{m}^{-2}$ of plot).

The effects of the different irrigation strategies on the contents of $\mathrm{Fe}, \mathrm{Mn}, \mathrm{Cu}, \mathrm{Zn}, \mathrm{Cr}, \mathrm{Ni}, \mathrm{Cd}$, and $\mathrm{Pb}$ in the soil, leaves, and berries were subjected to analysis of variance, and were compared by the Tukey test $(p<0.05)$. For analyses of the results of the micronutrient and heavy metal contents in the soil, variation at different depths in the treatments was not taken into consideration but rather variation among the treatments in each soil layer evaluated.

\section{RESULTS AND DISCUSSION}

\section{Soil moisture}

Soil moisture $(\theta)$ exhibited quite different behavior among the irrigation management treatments evaluated up to the $90 \mathrm{~cm}$ depth layer (Figure 1). As of interruption of irrigation (49 days after production pruning - dapp), there was a steady decline in $\theta$ in the treatments with regulated deficit irrigation (RDI) and deficit irrigation (DI) where, after water application in the RDI treatment (71 and 92 dapp), an increase of $\theta$ up to the $45 \mathrm{~cm}$ depth was

Table 1. Physical and chemical characteristics of the Ultisol cultivated with grapevines under different irrigation strategies

\begin{tabular}{|c|c|c|c|c|c|c|c|c|}
\hline Depth & BD & PD & Sand & Silt & Clay & $\mathrm{pH}\left(\mathrm{H}_{2} \mathrm{O}\right)$ & ECse & $\mathrm{H}+\mathrm{Al}$ \\
\hline $\mathrm{cm}$ & \multicolumn{2}{|c|}{$\mathrm{kg} \mathrm{dm}-3$} & \multicolumn{3}{|c|}{$\mathrm{g} \mathrm{kg}^{-1}$} & & $\mathrm{dS} \mathrm{m}^{-1}$ & $\mathrm{cmol}_{\mathrm{c}} \mathrm{dm}^{-3}$ \\
\hline $0-10$ & 1.32 & 2.53 & 779 & 149 & 72 & 6.79 & 0.38 & 1.29 \\
\hline $10-20$ & 1.37 & 2.53 & 778 & 133 & 89 & 6.57 & 0.32 & 1.62 \\
\hline $20-40$ & 1.35 & 2.51 & 738 & 116 & 146 & 6.41 & 0.21 & 1.59 \\
\hline $40-60$ & 1.32 & 2.52 & 716 & 104 & 180 & 6.27 & 0.28 & 1.74 \\
\hline \multirow[t]{3}{*}{$60-80$} & 1.32 & 2.53 & 686 & 101 & 213 & 5.87 & 0.24 & 1.71 \\
\hline & SB & CEC & SOM & $\mathbf{P}$ & $\mathbf{K}$ & $\mathbf{C a}^{2+}$ & $\mathrm{Mg}^{2+}$ & $\mathrm{Na}^{+}$ \\
\hline & \multicolumn{2}{|c|}{$\mathrm{cmol}_{\mathrm{c}} \mathrm{dm}^{-3}$} & $\mathrm{~g} \mathrm{~kg}^{-1}$ & \multicolumn{2}{|c|}{$\mathrm{mg} \mathrm{dm}^{-3}$} & \multicolumn{3}{|c|}{$\mathrm{cmol}_{\mathrm{c}} \mathrm{dm}^{-3}$} \\
\hline $0-10$ & 7.80 & 9.03 & 27.41 & 113.25 & 0.52 & 4.80 & 2.65 & 0.09 \\
\hline $10-20$ & 6.50 & 8.04 & 12.90 & 96.64 & 0.53 & 3.74 & 2.47 & 0.08 \\
\hline $20-40$ & 5.70 & 7.50 & 7.32 & 91.85 & 0.34 & 3.32 & 2.22 & 0.06 \\
\hline $40-60$ & 5.30 & 6.99 & 5.69 & 54.90 & 0.29 & 3.03 & 1.98 & 0.06 \\
\hline $60-80$ & 5.20 & 7.11 & 4.23 & 28.16 & 0.29 & 2.84 & 2.03 & 0.05 \\
\hline
\end{tabular}

BD: soil bulk density; PD: particle density; $\mathrm{pH}$ in water,1:2.5 v/v; ECse: electrical conductivity in the saturated paste extract; SB: sum of bases; CEC: cation exchange capacity; SOM: soil organic matter. 
observed. In the deeper soil layers (105 and $120 \mathrm{~cm}$ ), there was similar behavior in regard to variation of $\theta$ in all the treatments.

\section{Soil}

In figure 2 , the micronutrient contents in accordance with the different irrigation strategies are shown. The mean contents of available $\mathrm{Fe}^{2+}$ observed ranged from 3.9 to $37.3 \mathrm{mg} \mathrm{dm}^{-3}$, which was classified as very low to good, according to Alvarez et al. (1999). Among the irrigation strategies evaluated, no difference was observed in the contents of $\mathrm{Fe}^{2+}$ only at the depth of 0-10 cm (Figure 2a). At the depth of $10-20 \mathrm{~cm}$ under regulated deficit irrigation (RDI), the Fe content was higher when compared to the other irrigation strategies (FI and DI). Under conditions of greater water availability (full irrigation treatment - FI), reduction of $\mathrm{Fe}^{3+}$ to $\mathrm{Fe}^{2+}$ is favored, contributing to its movement in the soil profile beyond the layers evaluated, especially in sandy soils, as in this study (Table 1). Under conditions of greater water availability, dissolution and remobilization mechanisms of Fe come into action, which include reduction and complexation reactions (Schwertmann, 1991), favoring its greater concentration and leaching in soils with a low level of clay. In a study carried out by Hernández and Meurer (1998) in 10 soils of Uruguay, subject to temporal variations in oxidation-reduction conditions, it was observed that soil with low clay contents (cretaceous sandstones) exhibited lower Fe content, and a correlation was observed between $\mathrm{Fe}$ contents and clay contents of the soils. In a study evaluating eight soil samples from the provinces of Antwerp and West-Flanders in Belgium with known micronutrient and heavy metal values, and subjected to the treatments of dry soil, soil at field capacity, and saturated soil, Tack et al. (2006) observed that the events of wetting and drying of the soil changed the hydration, oxidation, and crystallinity status of the $\mathrm{Fe}$ and $\mathrm{Mg}$ oxides of the soil, favoring the release of these elements under wetter environments.

Soils under the FI and RDI treatments exhibited greater $\mathrm{Fe}$ content at the depth of $20-40 \mathrm{~cm}$ in relation to the soil under the DI treatment. For the 40-60 and 60-80 cm layers, soils under the DI and RDI treatments exhibited greater Fe contents in relation to the FI treatment. It may be observed that in the aerobic environment, the element Fe exhibits high thermodynamic stability and reduced solubility, persisting in the soil for a long period (Schwertmann and Taylor, 1989). This may have occurred under the condition of lower water availability in the more subsurface layers. In addition, in deeper soil layers, oxygen content becomes scarcer, making soil organisms use other elements as the terminal electron acceptor, resulting in its reduction.

According to Alvarez V et al. (1999), the available $\mathrm{Cu}$ contents observed are considered high $\left(>1.8 \mathrm{mg} \mathrm{dm}^{-3}\right)$ and are above those observed by Pietrzak and McPhail (2004) and Komárek et al. (2008)
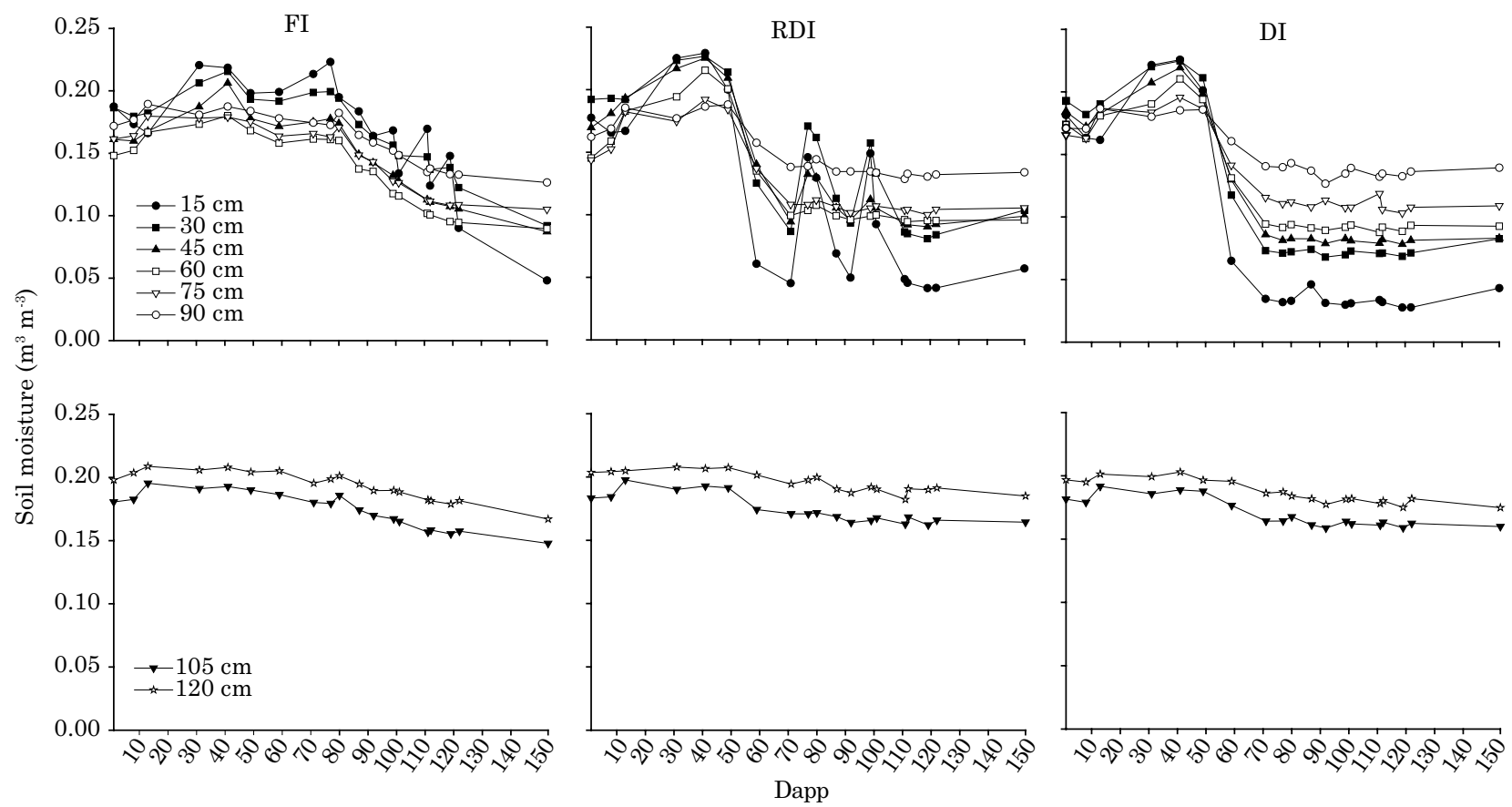

Figure 1. Soil moisture $(\theta)$ at the $15,30,45,60,75,90,105$, and $120 \mathrm{~cm}$ depths in accordance with irrigation strategies, with full irrigation - FI, regulated deficit irrigation - RDI, and deficit irrigation - DI. Dapp: days after production pruning. 

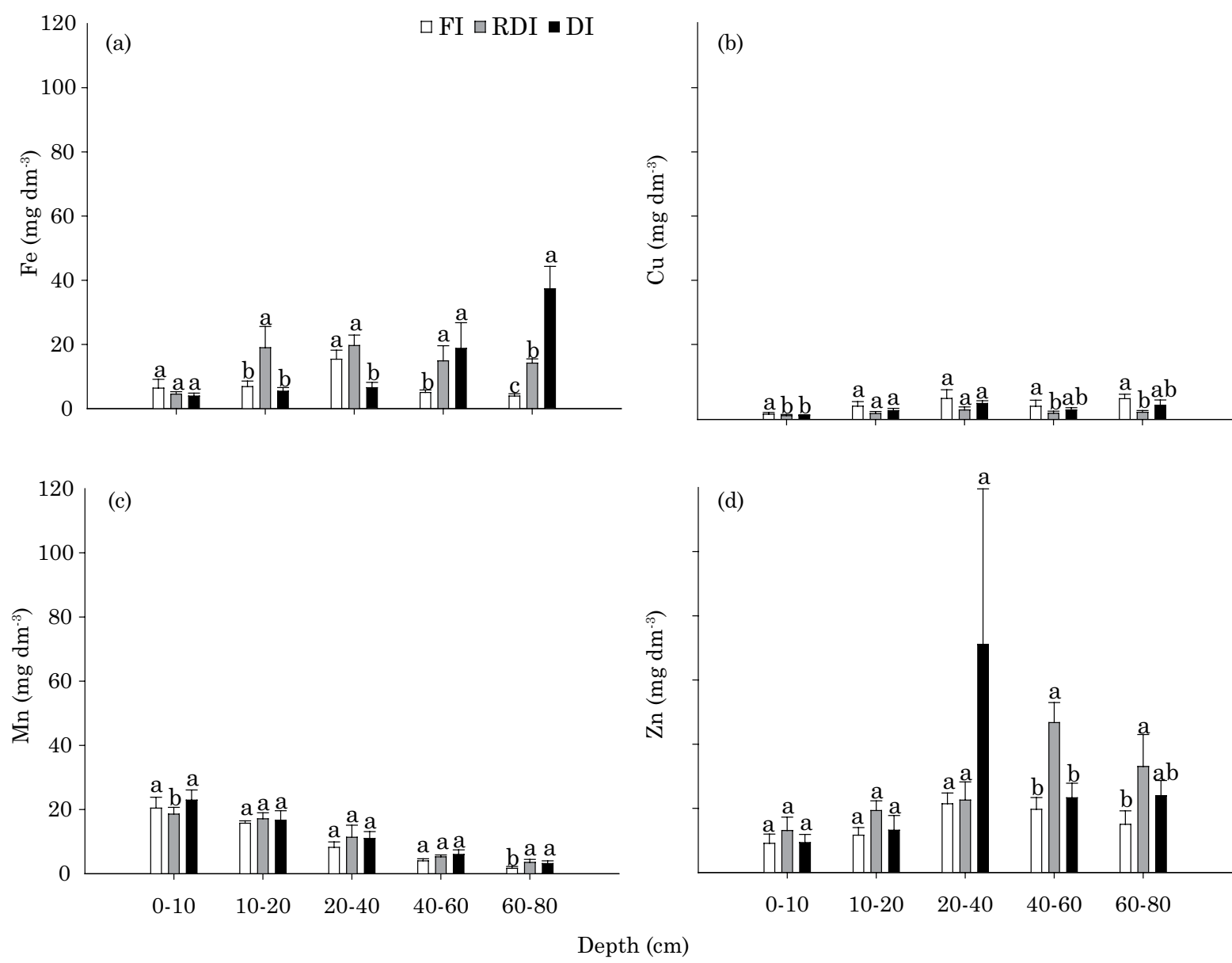

Figure 2. Micronutrient contents in the soil cultivated with grapevine in accordance with different irrigation strategies - full irrigation (FI), regulated deficit irrigation (RDI), and deficit irrigation (DI). Columns followed by the same letter at the same depth do not differ among themselves by the Tukey test at $5 \%$ of significance. The vertical deviation bars represent the standard deviation of the mean value $(n=12)$.

studying the accumulation of $\mathrm{Cu}$ in vineyard soils in Australia and the Czech Republic, respectively. The FI treatment showed greater $\mathrm{Cu}$ content in the $0-10 \mathrm{~cm}$ soil layer in relation to the other treatments (RDI and DI) (Figure 2b). In the 10-20 and $20-40 \mathrm{~cm}$ soil layers, there was no difference in the $\mathrm{Cu}$ content among the treatments evaluated. The FI treatment exhibited a greater $\mathrm{Cu}$ content in relation to the RDI treatment in the 40-60 and 60-80 cm layers, not differing from the DI treatment. There was a tendency toward an increase in $\mathrm{Cu}$ contents at greater depths, in spite of this element showing low mobility due to its strong adsorption to organic and inorganic soil colloids (Pietrzak and McPhail, 2004; Nascimento and Fontes, 2004; Komárek et al., 2008). The increase in the $\mathrm{Cu}$ contents in the soil in the deeper layers indicates that the contents in the surface layers are above the soil adsorption capacity and, thus, its percolation in the soil profile may have been facilitated, especially through the treatment with greater water availability. Costa et al. (2009), studying changes in the total contents of $\mathrm{Cu}$ in soils planted to grapes in the Vale do Submédio São Francisco, observed that there was an increase in the contents according to years of grape growing, attributed to human influence, with the greatest contents being found in the uppermost soil layer.

In addition, the slight increase in clay content with the increase in soil depth (Table 1) favored greater $\mathrm{Cu}$ contents in the FI treatment, which may be observed by their positive correlation value $\left(r=0.4058^{* *}\right.$, data not shown). Pombo and Klamt (1986), evaluating $\mathrm{Cu}$ adsorption in two soils in the state of Rio Grande do Sul also found significant correlation between $\mathrm{Cu}$ adsorption and the clay content of the soil.

The contents of available Mn observed ranged from 1.3 to $25.5 \mathrm{mg} \mathrm{dm}^{-3}$, which was considered very low $\left(<2 \mathrm{mg} \mathrm{dm}^{-3}\right)$ to very $\operatorname{good}\left(>12 \mathrm{mg} \mathrm{dm}^{-3}\right)$ (Alvarez et al., 1999). There were significant differences only in the $0-10$ and $60-80 \mathrm{~cm}$ layers, 
with the lowest content found in the RDI treatment in the $0-10 \mathrm{~cm}$ layer and in the FI treatment in the $60-80 \mathrm{~cm}$ layer (Figure 2c). Evaluating the mobility of six heavy metals $\left(\mathrm{Mn}^{2+}, \mathrm{Zn}^{2+}, \mathrm{Cd}^{2+}, \mathrm{Cu}^{2+}, \mathrm{Pb}^{2+}\right.$, and $\mathrm{Cr}^{3+}$ ) during percolation of a multispecies contaminant solution in a compacted residual soil of the municipality of Visconde do Rio Branco, MG, Nascentes (2006) observed that the mobility of $\mathrm{Mn}^{2+}$ practically did not depend on soil hydraulic conductivity. In a study evaluating the forms of $\mathrm{Mn}$ in reference soils of the state of Pernambuco, Oliveira and Nascimento (2006) observed that organic matter was mainly responsible for the retention and availability of $\mathrm{Mn}$ in the soil. Thus, the greater content of soil organic matter (SOM) found in the 0-10 and 10-20 cm layers (Table 1) allowed greater Mn contents $\left(r=0.8783^{* *}\right.$, data not shown). A strong correlation between the $\mathrm{Mn}^{2+}$ and the SOM contents was also observed in various studies (Bayer et al., 2002; Motta et al., 2002). This occurs due to the $\mathrm{Mn}^{2+}$ being adsorbed to the functional groups of the SOM, such as carboxylic and phenolic groups, in the form of outer and inner sphere complexes (Lakatos and Meisel, 1977). In the outer sphere complex, the Mn is adsorbed only through electrostatic attraction (attraction between opposite charges), while in the inner sphere complex, the $\mathrm{Mn}$ is adsorbed by covalent bonding (sharing electrons).

Just as for $\mathrm{Cu}$, a tendency toward an increase in the Zn levels at greater depth was observed. The available $\mathrm{Zn}$ contents observed were much above the reference value considered very good for crops $\left(>2.2 \mathrm{mg} \mathrm{dm}^{-3}\right)$, according to Alvarez et al. (1999). Silva et al. (2003), evaluating extractors for quantification of $\mathrm{Zn}$ and $\mathrm{Cu}$ in soils planted to soybean in the State of Parana, Brazil, observed available $\mathrm{Zn}$ contents ranging from 0 to $10 \mathrm{mg}$ $\mathrm{dm}^{-3}$ after extraction by Mehlich-1. Just as $\mathrm{Cu}$, $\mathrm{Zn}$ tends to accumulate in the surface layer of the soil, due to low mobility in the soil profile (Bertol et al., 2010). Therefore, in general, they exhibit low leaching potential. However, continued applications of these elements to the soil may lead to losses to the subsurface. There was no difference in the available $\mathrm{Zn}$ contents among the treatments evaluated in the $0-10,10-20$, and $20-40 \mathrm{~cm}$ soil layers (Figure 2d). For the 40-60 and 60-80 cm layers, the RDI treatment exhibited a greater $\mathrm{Zn}$ content than the FI treatment.

For $\mathrm{Cr}$ contents, a significant difference was observed among the treatments for all the soil layers evaluated (Figure 3a). Lower water availability in the RDI and DI treatments contributed to greater contents of this element in the $0-10$ and $10-20 \mathrm{~cm}$ soil layers. $\mathrm{Cr}$ is concentrated in the soil surface layers in the form of $\mathrm{Cr}^{3+}$, and $\mathrm{Cr}^{6+}$ is unstable and rapidly converted to $\mathrm{Cr}^{3+}$ by the action of organic matter (Bergmann, 1992). In the 20-40 cm layer, the RDI treatment was that which favored greater concentration of $\mathrm{Cr}$ in the soil. In the $40-60 \mathrm{~cm}$ soil layer, the DI treatment exhibited greater $\mathrm{Cr}$ content when compared to the other treatments, while in the 60-80 cm layer, the FI and DI treatments exhibited greater $\mathrm{Cr}$ content in relation to the RDI treatment. Although the $\mathrm{Cr}$ element exists in diverse states of oxidation, only $\mathrm{Cr}^{3+}$ and $\mathrm{Cr}^{6+}$ are sufficiently stable to occur in the environment. The $\mathrm{Cr}^{6+}$ has more mobility than $\mathrm{Cr}^{3+}$ because its anions are easily transported through the soil (Shrivastava et al., 2002).

The Cd content was greater in the FI treatment in relation to the DI treatment only in the $20-40 \mathrm{~cm}$ soil layer (Figure $3 b$ ). For the other soil layers evaluated, no difference was observed in the $\mathrm{Cd}$ contents among the diverse treatments. Soils derived from igneous rocks contain from 0.1 to $0.3 \mathrm{mg} \mathrm{kg}-1$ of $\mathrm{Cd}$; those derived from metamorphic rocks, from 0.1 to $1.0 \mathrm{mg} \mathrm{kg}^{-1}$ of $\mathrm{Cd}$; and in those derived from sedimentary rocks, the content may be up to $10.0 \mathrm{mg} \mathrm{kg}^{-1}$ of Cd (Kabata-Pendias, 2011). Campos et al. (2007) found mean values of $0.66 \mathrm{mg} \mathrm{kg}-1$ of $\mathrm{Cd}$ in diverses Brazilian Oxisols. The Cd contents permitted for non-contaminated soils, according to Kabata-Pendias (2011), are less than $1.0 \mathrm{mg} \mathrm{kg-1}$, although in agricultural soils in China (SEPAC, 1995) and the Czech Republic (Komárek et al., 2008), these limits are considered to be around 0.3 and $0.4 \mathrm{mg} \mathrm{kg}^{-1}$, respectively. It should be noted that the reference values for quality are defined in accordance with the total contents and, for that reason, comparison with the contents observed in the study is not possible.

Differences were not observed in the Ni contents in the $0-10,40-60$, and $60-80 \mathrm{~cm}$ layers (Figure 3c). For the $10-20 \mathrm{~cm}$ layer, the RDI treatment had greater $\mathrm{Ni}$ content in the soil when compared to the FI treatment. As for the 20-40 cm layer, the FI treatment had greater $\mathrm{Ni}$ content in the soil in relation to the DI treatment, not differing from the RDI treatment. Ni is the most mobile heavy metal in the soil (Antoniadis and Tsadilas, 2007); however, the most important factor that determines the distribution of $\mathrm{Ni}$ between the solid and soluble phase of the soil is $\mathrm{pH}$, and its availability is inversely related to this index (Uren, 1992). There was no difference in the $\mathrm{Pb}$ contents among the treatments evaluated in all the soil layers studied (Figure 3d), showing that the different irrigation strategies did not affect the $\mathrm{Pb}$ concentration in the soil.

\section{Leaf}

The different irrigation strategies did not affect the micronutrient and heavy metal concentration in the grape leaves (Figure 4a,b). The soil volume utilized and the close contact between the surface of the roots and the soil are essential for effective uptake of water, micronutrients, and heavy metals by the roots. The growth of root hairs, with consequent increase in surface area, favors 

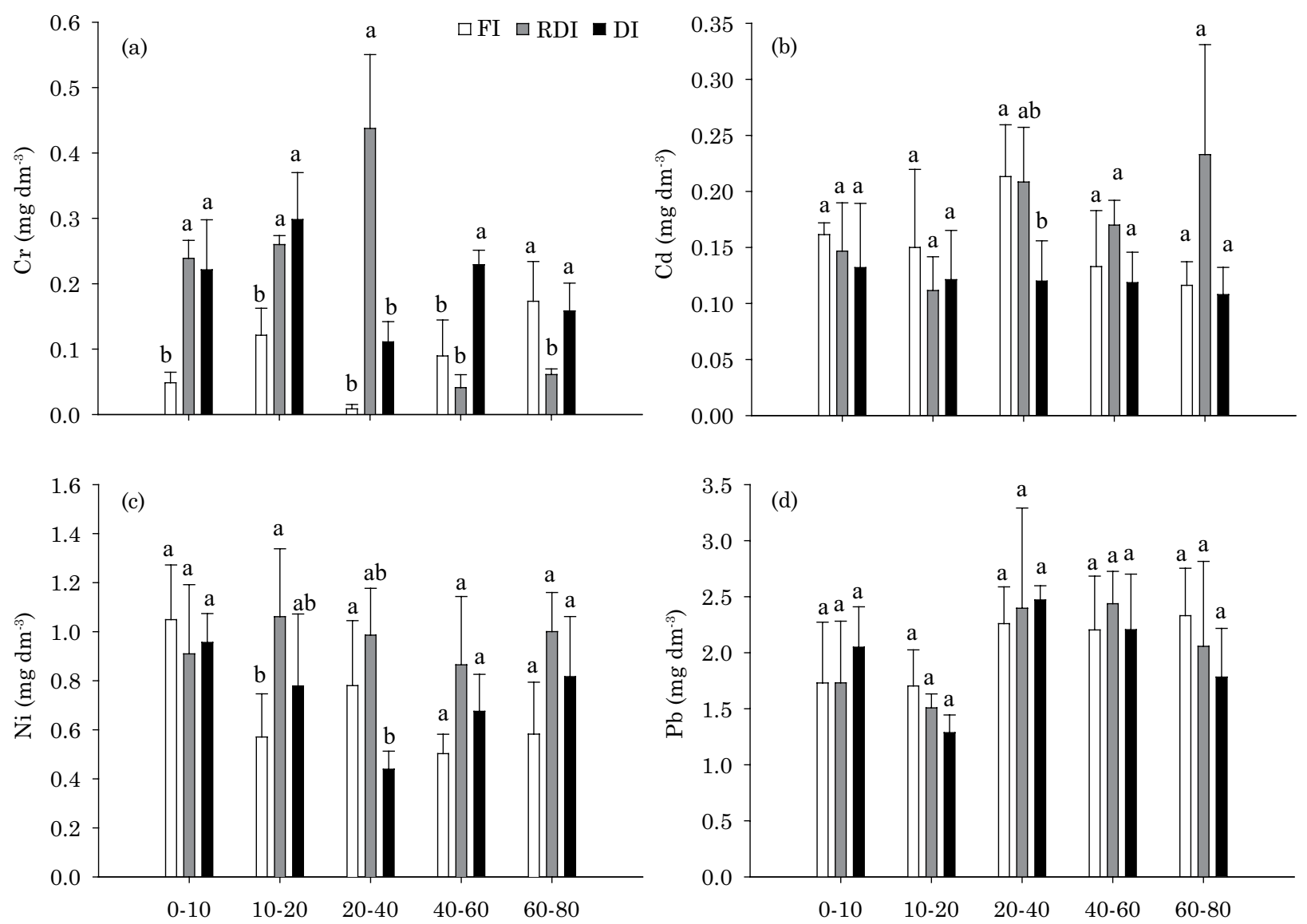

Depth (cm)

Figure 3. Heavy metal contents in the soil cultivated with grapevines in accordance with different irrigation strategies - full irrigation (FI), regulated deficit irrigation (RDI), and deficit irrigation (DI). Columns followed by the same letter at the same depth do not differ among themselves by the Tukey test at $5 \%$ of significance. The vertical deviation bars represent the standard deviation of the mean value $(n=12)$.

maximization of root-soil contact, increasing water, micronutrient, and heavy metal uptake capacity. Under water stress condition, plants dedicate more biomass to the root system, thus making it possible to increase nutrient uptake capacity and, consequently, nutrient accumulation in the plant shoots. Barbosa and Barbosa (1996) affirm that, in general, greater root growth in relation to the plant shoots is an adaptive trait, common to plants subjected to water stress. Thus, we believe that this morphological adaptation, increasing the volume of the root system under water deficit conditions, allowed similar micronutrient and heavy metal contents in the leaves among the treatments evaluated in the present study.

The Mn and Ni contents were greater than those of the other micronutrients and heavy metals evaluated. According to Marenco and Lopes (2005), the Mn content in the leaf normally shows positive interaction with the $\mathrm{Ni}$ content.

The mean leaf contents of $\mathrm{Cu}(44.58 \mathrm{~g} \mathrm{~kg}-1)$, Zn (114.25 mg kg-1), and Mn (387.50 mg kg-1) are above the critical level $\left(>20,>50\right.$, and $>300 \mathrm{mg} \mathrm{kg}^{-1}$, respectively) (Faria and Soares, 2004). In contrast, these values are in agreement with those found by Giovannini (2008). In spite of these elements appearing in the excessive range of leaf concentration, no visual symptom of toxicity was observed in the field. High values of $\mathrm{Cu}, \mathrm{Zn}$, and $\mathrm{Mn}$ have been attributed to the genesis of the soils in the region, which under ideal conditions of redox reactions may favor the solubilization of these elements (Faria and Soares, 2004). Normally, leaf analyses of the grape crop in the Vale do Submédio São Francisco have shown very high Mn contents, without, however, affecting yield, in agreement with the results found in this study. 

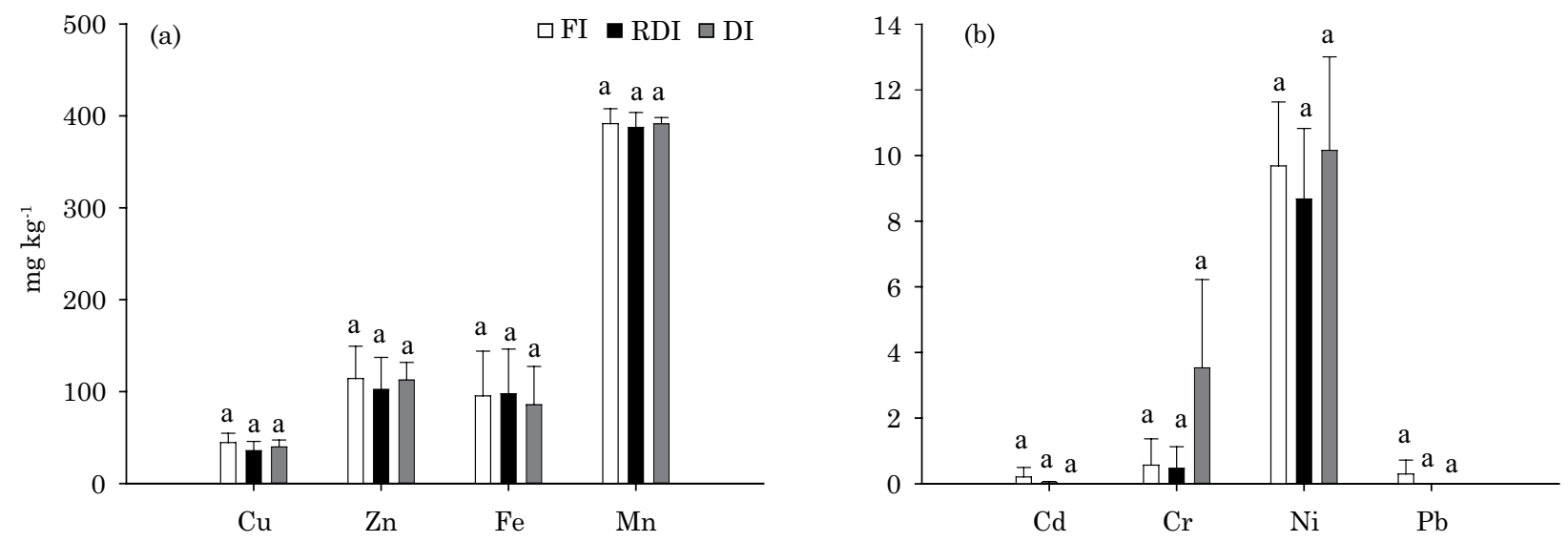

Figure 4. Micronutrient and heavy metal contents in grapevine leaves in accordance with different irrigation strategies - full irrigation (FI), regulated deficit irrigation (RDI), and deficit irrigation (DI). Columns followed by the same letter do not differ among themselves by the Tukey test at $5 \%$ of significance. The vertical deviation bars represent the standard deviation of the mean value $(n=12)$.

In contrast, the leaf contents of $\mathrm{Fe}$ (85.60-95.28 $\mathrm{mg} \mathrm{kg}^{-1}$ ) observed are within the range considered adequate for the grapevine (60-180 $\mathrm{mg} \mathrm{kg}^{-1}$ ) (Faria and Soares, 2004). The contents of $\mathrm{Cd}$ (0.0-0.21 mg kg-1), Cr (0.47-3.53 mg kg-1), and $\mathrm{Pb}$ (0.0-0.30 $\mathrm{mg} \mathrm{kg}^{-1}$ ) observed in the leaf tissue of the grape plants are considered adequate, which, according to Adriano (1986), should be in the range of 0.1-0.5 mg kg-1 for $\mathrm{Pb}$ and 0.05-0.5 mg kg-1 for $\mathrm{Cr}$. Evaluating the concentration of $\mathrm{Pb}$ and $\mathrm{Cd}$ in different parts of the grapevine in the village of Brestnik, Bulgaria, Angelova et al. (1999) found values of $19 \mathrm{mg} \mathrm{kg}^{-1}$ of $\mathrm{Pb}$, and $0.5 \mathrm{mg} \mathrm{kg}^{-1}$ of $\mathrm{Cd}$ in leaf samples in the grape maturation phase. These same authors affirm that there is a tendency for an increase in the concentrations of $\mathrm{Pb}$ and $\mathrm{Cd}$ as vegetation ages, up to grape maturity.

The Ni contents (8.68 to $10.16 \mathrm{mg} \mathrm{kg}^{-1}$ ) observed in the grape leaves are greater than the range considered adequate ( 0.1 to $\left.5 \mathrm{mg} \mathrm{kg}^{-1}\right)$, according to Adriano (1986). This author affirms that the Ni content in plant dry matter varies depending on the species, part of the plant, phenological stage, soil content, and soil acidity, among other factors. Possibly, the grape cultivar studied, and the $\mathrm{Ni}^{2+}$ contents observed in the soil, associated with the fact of this element being very mobile in the soil (Antoniadis and Tsadilas, 2007), contributed to high contents of this nutrient in the leaves.

\section{Grape}

The different irrigation strategies affected grape yield, with the FI treatment obtaining greater yield $\left(6,600 \mathrm{~kg} \mathrm{ha}^{-1}\right)$ in relation to the other treatments $\left(5,130 \mathrm{~kg} \mathrm{ha}^{-1}\right.$ for RDI and $4,000 \mathrm{~kg} \mathrm{ha}^{-1}$ for DI). Several studies also report variation in grape yield when grown under different irrigation strategies. In most situations, there were greater yields with full irrigation (Esteban et al., 2001; Nadal and Lampreave, 2007). Under water stress conditions, berry size and grape yield is normally less due to lower water availability for cell division and elongation (Esteban et al., 2002). In a study evaluating the effect of irrigation management practices on aspects of ecophysiology and production of the grapevine cv. Syrah/Paulsen 1103 in the Brazilian semi-arid region, Bassoi et al. (2011) also observed that water deficit generally results in lower grape yields. Water deficit between flower opening (anthesis) and the beginning of berry maturation (veraison) reduces the final berry size in an irreversible manner and, consequently, reduces yield, even if there is wetting after veraison. In the phase between veraison and harvest, the berries increase in volume, weight, and sugar content. Interruption of water application in this study occurred at 49 dapp, in the bunch closure phase (before veraison, which occurred at 85 dapp), and the water availability in the soil in the RDI and DI treatments steadily declined (Figure 1), resulting in lower yields in these treatments is relation to the treatment under full irrigation.

The inorganic components of the grapes significantly affect wine production and quality, and they are fundamental for human nutrition (Ribéreau-Gayon et al., 2006). The quality of the must and, consequently, of the wine depend, in part, on the metallic elements present (Puig-Deu et al., 1994). Elements such as $\mathrm{Fe}, \mathrm{Cu}, \mathrm{Al}, \mathrm{Zn}$, and $\mathrm{Ni}$ in excess contribute to the formation of precipitates and may cause an effect on color, aroma, or flavor of the wine (Galani-Nikolakaki et al., 2002). In addition, it is known that an excess of $\mathrm{Fe}$ and $\mathrm{Cu}$ determine 

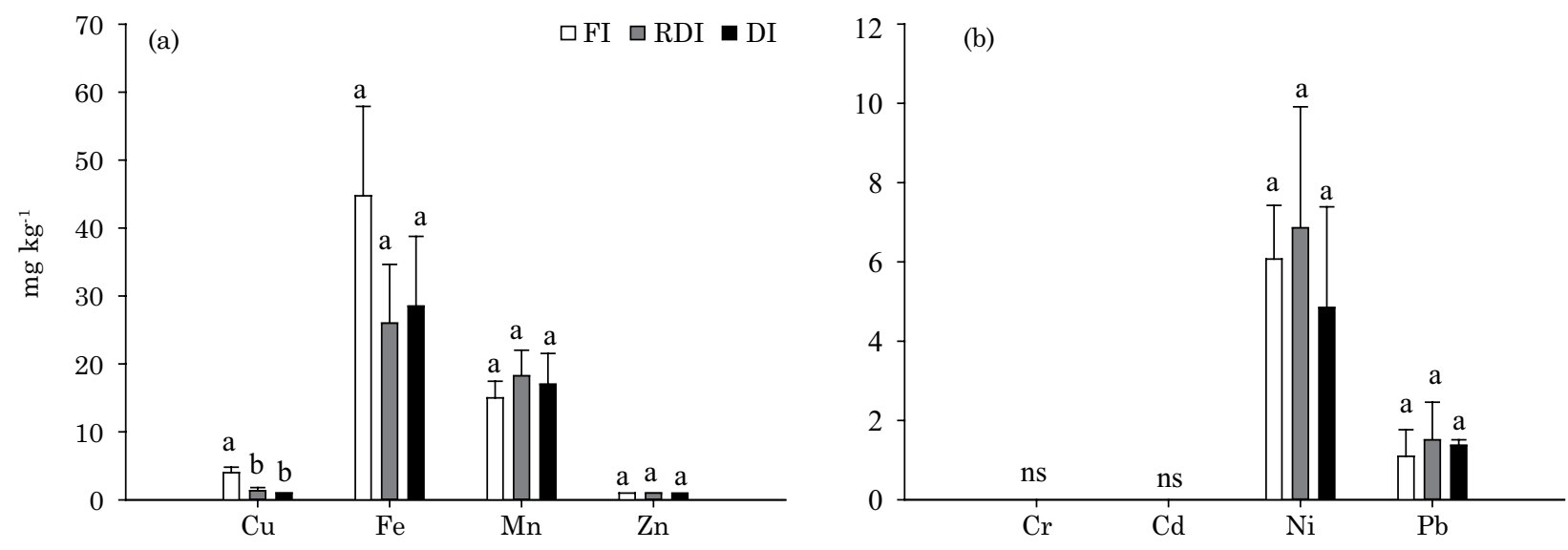

Figure 5. Micronutrient and heavy metal contents in grapevine under different irrigation strategies - full irrigation (FI), regulated deficit irrigation (RDI), and deficit irrigation (DI). Columns followed by the same letter do not differ among themselves by the Tukey test at $5 \%$ of significance. The vertical deviation bars represent the standard deviation of the mean value $(n=12)$.

wine turbidity, may delay fermentation during winemaking, and are important causes of instability, as in the case of formation of unstable colloids resulting from a reaction between two unstable cations, proteins and phosphoric acids (iron and copper casse) (Sofo et al., 2012).

The micronutrient contents in the grape showed a significant difference only for $\mathrm{Cu}$, among the treatments evaluated, and the FI treatment obtained a greater concentration in relation to the RDI and DI treatments (Figure 5a), which may be a risk for the wines, causing instability and turbidity. Therefore, adoption of deficit irrigation is recommended to avoid compromising the stability of tropical wines from the Northeast of Brazil. So that nutrients may be taken up by the plants, there must be transport in the soil by processes of mass flow and diffusion (Silva and Araujo, 2005). The element Fe moves in the soil through mass flow; whereas, for $\mathrm{Zn}$, diffusive flow or diffusion is the most important form of transport, given its low concentration in the soil solution. According to Silva and Mendonça (2007), among the micronutrients, $\mathrm{Cu}$ is one of the least mobile in the soil due to its strong adsorption on the organic and inorganic colloids of the soil, and diffusion is one of the main means of transport of this element. Greater availability of water in the full irrigation treatment favored the transport and, consequently, uptake of $\mathrm{Cu}$ by the grape crop.

In a study evaluating the effect of water deficit on nutrient export in different grape varieties in the region of Parma, Idaho, USA, Shellie and Brown (2012) observed that the concentrations of $\mathrm{Zn}, \mathrm{Fe}$, and $\mathrm{Mn}$ in the grape were not affected by the irrigation regime, but differed among the nine cultivars. Also evaluating grape composition affected by water availability in five-year-old vineyards in
Italy, Sofo et al. (2012) observed that the contents of $\mathrm{Cu}, \mathrm{Fe}$, and $\mathrm{Zn}$ in the grape were greater in the irrigated treatment $\left(0.23 \mathrm{mg} \mathrm{kg}^{-1}\right.$ of $\mathrm{Cu}, 0.24 \mathrm{mg} \mathrm{kg}^{-1}$ of $\mathrm{Fe}$, and $0.47 \mathrm{mg} \mathrm{kg}^{-1}$ of $\mathrm{Zn}$ ) in relation to the treatment without irrigation $\left(0.11 \mathrm{mg} \mathrm{kg}^{-1}\right.$ of $\mathrm{Cu}$, $0.064 \mathrm{mg} \mathrm{kg}^{-1}$ of $\mathrm{Fe}$, and $0.23 \mathrm{mg} \mathrm{kg}^{-1}$ of $\mathrm{Zn}$ ). For the present study, the FI treatment had $4.0 \mathrm{mg} \mathrm{kg}^{-1}$ more $\mathrm{Cu}$, in relation to the DI treatment.

There was no difference in the $\mathrm{Cr}, \mathrm{Cd}, \mathrm{Ni}$, and $\mathrm{Pb}$ contents among the treatments evaluated (Figure 5b). Possibly, expansion of the root system in the soil profile in search of water, stimulated by water deficit (Santos and Carlesso, 1998), allowed for greater uptake of heavy metals and, consequently, their accumulation in the berries similar to the conditions under full irrigation. In general, greater root growth in relation to the shoots is an adaptive trait, common to plants subjected to water stress (Barbosa and Barbosa, 1996), resulting in an increase in nutrient uptake capacity. It should be noted that during wine production, there may be partial elimination of metals by the processes of precipitation under the form of organic salts and through uptake and adsorption by yeasts and bacteria used during grape fermentation (Catarino et al., 2008). Thus, the occurrence of metals at very high concentrations in wine indicates, in general, the occurrence of contaminations after fermentation (Jackson, 2000).

\section{CONCLUSIONS}

The heavy metal and micronutrient contents in the soil exhibited a stochastic pattern in relation to the different irrigation strategies. 
The different irrigation strategies did not have an effect on the micronutrient and heavy metal contents in the grape leaf, and are below the values considered toxic to the plant.

The greater availability of water in the full irrigation (FI) treatment favored greater $\mathrm{Cu}$ content in the grape (berries). Therefore, adoption of deficit irrigation is recommended to avoid compromising the stability of wines from the Northeast of Brazil by $\mathrm{Cu}$. The different irrigation strategies did not affect the heavy metal contents in the grape.

\section{REFERENCES}

Adriano DC. Trace elements in the terrestrial environment. New York: Springer-Verlag; 1986.

Albuquerque TCS, Silva DJ, Faria CMB, Pereira JR. Nutrição e adubação. In: Soares JM, Leão PCS, editores. A viticultura no Semiárido Brasileiro. Petrolina: Empresa Brasileira de Pesquisa Agropecuária; 2009. p.431-80.

Alvarez V VH, Novais RF, Barros NF, Cantarutti RB, Lopes AS. Interpretação dos resultados das análises de solos. In: Ribeiro AC, Guimarães PTG, Alvarez V VH, editores. Recomendação para o uso de corretivos e fertilizantes em Minas Gerais: 5a Aproximação. Viçosa, MG: Comissão de Fertilidade do Solo do Estado de Minas Gerais; 1999. p.25-32.

Angelova VR, Ivanov AS, Braikov DM. Heavy metals (Pb, Cu, Zn and $\mathrm{Cd}$ ) in the system soil - grapevine - grape. J Sci Food Agric. 1999;79:713-21.

Antoniadis V, Tsadilas CD. Sorption of cadmium, nickel, and zinc in mono- and multimetal systems. Appl Geochem. 2007;22:2375-80.

Azevedo PV, Silva BB, Silva VPR. Water requirements of irrigated mango orchards in Northeast Brazil. Agric Water Manage. 2003;58:241-54.

Barbosa DC, Barbosa MCA. Crescimento e estabelecimento de plantas. In: Sampaio EVSB, Mayo SJ, Barbosa MRV, editores. Pesquisa botânica nordestina: Progresso e perspectivas. Recife: Sociedade Botânica do Brasil, 1996. p.173-7.

Bassoi LH, Dantas BF, Lima Filho JMP, Lima MAC, Leão PCS, Silva DJ, Maia JLT, Souza CR, Silva JAM, Ramos MM. Preliminary results of a long term experiment about RDI and PRD irrigation strategies in wine grape in Sao Francisco Valley, Brazil. Acta Hortic. 2007;754:275-82.

Bassoi LH, Gonçalves SO, Santos ARL, Silva JÁ, Lima ACM. Influência de manejos de irrigação sobre aspectos de ecofisiologia e de produção da videira cv. Syrah/Paulsen 1103. Irriga. 2011;16:395-402.

Bayer C, Dick DP, Ribeiro GM, Scheuermann KK. Carbon stocks in organic matter fractions as affected by land use and soil management, with emphasis on no-tillage effect. Ci Rural. 2002;32:401-6.

Bergmann W. Nutritional disorders of plants: developments, visual and analytical diagnosis. New York: Gustav Fischer; 1992.

Bertol OJ, Fey E, Favaretto N, Lavoranti OJ, Rizzi NE. Mobilidade de $\mathrm{P}$, $\mathrm{Cu}$ e $\mathrm{Zn}$ em colunas de solo sob sistema de semeadura direta submetido às adubações mineral e orgânica. R Bras Ci Solo. 2010;34:1841-50.

Campos ML, Pierangeli MAP, Gilherme LRG, Marques JJ, Curi N. Baseline concentration of heavy metal in Brazilian Latosols. Commun Soil Sci Plant Anal. 2007;34:547-57.

Catarino S, Curvelo-Garcia AS, Sousa RB. Revisão: Elementos contaminantes nos vinhos. Ci Tecnol Vitivin. 2008;23:3-19.

Claessen MEC, organozador. Manual de métodos de análise de solo. $2^{\text {a }}$ ed. Rio de Janeiro: Centro Nacional de Pesquisa de Solos; 1997.

CostaWPLB, Fabricio Neta AB, Nascimento CWA, Cunha KPV, Silva DJ. Alterações nos teores totais de $\mathrm{Cu}$ e $\mathrm{Zn}$ em solos cultivados com videira. In: Anais do $32^{\circ}$ Congresso Brasileiro de Ciência do Solo [CD-ROM]; 2-7 ago 2009; Fortaleza. Fortaleza: Sociedade Brasileira de Ciência do Solo; 2009.

Cunha RCA, Camargo OA, Kinjo T. Eluição de duas fontes de zinco aplicadas em horizonte superficial de um Podzólico e de um Latossolo. R Bras Ci Solo. 1996;20:371-8.

Dry PR, Loveys BR. Factors influencing grapevine vigour and the potential for control with partial rootzone drying. Aust J Grape Wine Res. 1998;4:140-8.

Esteban MA, Villanueva MJ, Lissarrague JR. Effect of irrigation on changes in the anthocyanin composition of the skin of $\mathrm{cv}$ Tempranillo (Vitis vinifera $\mathrm{L}$ ) grape berries during ripening. J Sci Food Agric. 2001;81:409-20.

Esteban MA, Villanueva MJ, Lissarrague JR. Relationships between different berry components in Tempranillo (Vitis vinifera L.) grapes from irrigated and nonirrigated vines during ripening. J Sci Food Agric. 2002;82:1136-46.

Fadigas FS, Amaral Sobrinho NMB, Mazur N, Anjos LHC, Freixo AA. Proposição de valores de referência para a Concentração natural de metais pesados em solos brasileiros. R Bras Eng Agríc Amb. 2006;10:699-705.

Faria CMB, Soares JM. Distúrbio fisiológico em videira no Submédio São Francisco. Petrolina: Empresa Brasileira de Pesquisa Agropecuária; 2004.

Galani-Nikolakaki S, Kallithrakas-Kontos N, Katsanos AA. Trace element analysis of cretan wines and wine products. Sci Total Environ. 2002;285:155-63.

Giovannini E. Produção de uvas para vinho, suco e mesa. 3a ed. Porto Alegre: Renascença; 2008.

Hernández J, Meurer EJ. Adsorção de fósforo e sua relação com formas de ferro em 10 solos do Uruguai. R Bras Ci Solo. 1998;2:223-30.

Hooda PS. Trace elements in soils. Chichester: John Wiley and Sons; 2010.

Jackson RS. Wine science - Principles, practice, perception. 2a ed. San Diego: Academic Press; 2000.

Jackson DI, Lombard PB. Environmental and management practices affecting grape composition and wine quality - a review. Am J Enol Vitic. 1993;44:409-30.

Kabata-Pendias A. Trace elements in soils and plants. $4^{\text {th }}$ ed. Boca Raton: Chemical Rubber Company Press, 2011.

Keller M, Smithyman RP, Mills LJ. Interactive effects of deficit irrigation and crop load on Cabernet Sauvignon in an arid climate. Am J Eno. Vitic. 2008;59:221-34. 
Komárek M, Szácová J, Rohoscova M, Javorská H, Chrastný V, Balik J. Copper contamination of vineyard soils from small wine producers: A case study from the Czech Republic. Geoderma. 2008;147:16-22.

Lakatos BT, Meisel TJ. EPR espectra of humic acids and their metal complexes. Geoderma. 1977;19:319-38.

Larcher W. Ecofisiologia vegetal. 2a ed. São Carlos: Rima; 2004.

Lasat MM. Phytoextraction of toxic metal: A review of biological mechanisms. J Environ Qual. 2002;31:109-20.

Marenco RA, Lopes NF. Fisiologia vegetal: Fotossíntese, respiração, relações hídricas e nutrição mineral. Viçosa, MG: Universidade Federal de Viçosa; 2005.

McCarthy MG. The effect of transient water deficit on berry development of Shyraz Vitis vinifera L. Aust J Grape Wine Res. 1997;3:102-8.

Miyazawa M, Pavan MA, Muraoka T, Carmo CAFS, Melo WJ. Análise química de tecido vegetal. In: Silva FC, editor. Manual de análises químicas de solos, plantas e fertilizantes. Brasília, DF: Empresa Brasileira de Pesquisa Agropecuária; 2009. p.192-233.

Motta AC, Reeves DW, Touchton JT. Tillage intensity effects on chemical indicators of soil quality in two coastal plain soils. Commun Soil Sci Plant Anal. 2002;33:913-32.

Nadal M, Lampreave M. Experiencias de riego en la vid. In: Montsant DO, editor. Fundamentos, aplicación y consecuencias del riego en la vid. Madrid: Editorial Agrícola Española; 2007. p.231-56.

Nascentes R. Estudo da mobilidade de metais em solos residual compactados [tese]. Viçosa, MG: Universidade Federal de Viçosa; 2006.

Nascimento CWA, Fontes RLF. Correlação entre características Latossolos e parâmetros de equações de adsorção de cobre e zinco. R Bras Ci Solo. 2004;28:965-71.

Novais RF, Smyth TJ. Fósforo em solo e planta em condições tropicais. Viçosa, MG: Folha de Viçosa; 1999.

Oliveira AB, Nascimento CWA. Formas de manganês e ferro em solos de referência de Pernambuco. R Bras Ci Solo. 2006;30:99-110.

Pietrzak U, McPhail DC. Copper accumulation, distribution and fractionation in vineyard soils of Victoria, Australia. Geoderma. 2004;122:151-66.

Pires JLF, Soprano E, Cassol B. Adaptações morfofisiológicas da soja em solo inundado. Pesq Agropec Bras. 2002;37:41-50.

Pombo LCA, Klamt E. Adsorção de zinco e cobre de dois solos do Estado do Rio Grande do Sul. R Bras Ci Solo. 1986;10:191-4.

Puig-Deu M, Lamuela-Daventós RM, Buxaderas S, Torre-Boronat C. Determination of copper and iron must: Comparison of wet and dry ashing. Am J Enol Vitic., 1994;45:25-8.

Ribéreau-Gayon P, Glories Y, Maujeon A, Dubourdieu D, Donèche B. Handbook of enology. 2nd ed. Chichester: John Wiley and Sons; 2006.
Santos RF, Carlesso R. Déficit hídrico e os processos morfológicos e fisiológicos das plantas. R Bras Eng Agríc Amb. 1998;2:287-94.

Schwertmann U, Taylor RM. Iron oxides. In: Dixon JB, Weed SB, editors. Minerals in soil environments. 2nd ed. Madison: Soil Science Society of America; 1989. p.379-438.

Schwertmann U. Solubility and dissolution of iron oxides. Plant Soil. 1991;130:1-25.

Shellie K, Brown B. Influence of deficit irrigation on nutrient indices in wine grape (Vitis vinifera L.). Agric Sci. 2012;3:268-73.

Shrivastava R, Upreti RK, Seth PK, Chaturvedi UC. Effects of chromium on the immune system. FEMS Immunol Medic Microbiol. 2002;34:1-7.

Silva DJ, Araújo CAS. Agricultura irrigada: A importância da adubação. In: Anais do $30^{\circ}$ Congresso Brasileiro de Ciência do Solo [CD-ROM]; 17-22 jul 2006; Recife. Recife: Sociedade Brasileira de Ciência do Solo; 2005.

Silva FC, organizador. Manual de análises químicas de solos, plantas e fertilizantes. 2a ed. Brasília, DF: Empresa Brasileira de Pesquisa Agropecuária; 2009.

Silva IR, Mendonça ES. Matéria orgânica do solo. In: Novais RF, Alvarez V VH, Fontes RLF, Cantarutti RB, Neves JCL, editores. Fertilidade do solo. Viçosa, MG: Sociedade Brasileira de Ciência do Solo; 2007. p.275-374.

Silva JAM. Irrigação lateralmente alternada e com déficit hídrico na videira cv. Petite Syrah [tese]. Viçosa, MG: Universidade Federal de Viçosa; 2005.

Silva MAG, Muniz AS, Mata JDV, Cegana ACV. Extratores para a quantificação do zinco e do cobre em solos cultivados com soja. Acta Sci. 2003;26:361-6.

Sofo A, Nuzzo V, Tatarani G, Manfra M, Nisco M, Scopa A. Berry morphology and composition in irrigated and non-irrigated grapevine (Vitis vinifera L.). J Plant Physiol. 2012;169:1023-31.

State Environmental Protection Administration of China SEPAC. Environmental quality standard for soils. GB 15618 1995. Beijing: State Environmental Protection Administration of China; 1995 [accessed on Oct 15, 2000]. Available at: https:// www.google.com.br/search?tbm=bks\&hl=pt-BR\&q=SEPAC+Env iroment+Quality+Standard+for+Soil+\%28GB+15618-1995\%29.

Tack FMG, Ranst E, Lievens C, Vandenberghe RE. Soil solution $\mathrm{Cd}, \mathrm{Cu}$ and $\mathrm{Zn}$ concentrations as affected by short-time drying or wetting: The role of hydrous oxides of $\mathrm{Fe}$ and $\mathrm{Mn}$. Geoderma. 2006;37:83-9.

Tonietto J. Les macroclimats viticoles mondiaux et l'influence du mésoclimat sur la typicité de la Syrah et du Muscat de Hambourg dans le sud de la France: Méthodologie de caractérisation [tese]. Montpellier: École Nationale Supérieure Agronomique de Montpellier; 1999.

Uren NC. Forms, reactions, and availability of nickel in soils. Adv Agron. 1992;48:141-203.

Xue H, Nhat PH, Gachter R, Hooda PS. The transport of $\mathrm{Cu}$ and Zn from agricultural soils to surface water in a small catchment. Adv Environ Res. 2003;8:69-76. 